\title{
GEORGE OWEN REES, MD, FRS (1813-89): PIONEER OF MEDICAL CHEMISTRY
}

\author{
by
}

NOEL G. COLEY*

The practical utility of chemistry in medicine was already beginning to be recognized by some physicians in the second half of the eighteenth century, and in 1770 the United Hospitals (St Thomas's and Guy's) established in London a joint medical school in which Guy's was to provide instruction in the so-called "collateral sciences"-botany, physiology, natural philosophy (i.e. physics), and chemistry-all of which were then new subjects in the medical curriculum. The school's success owed much to the initiative of Guy's treasurer, Benjamin Harrison, ${ }^{1}$ whose enthusiasm and foresight helped to lay the foundations for innovative teaching and research in scientific medicine at the hospital. During the early years of the nineteenth century, the chemistry curriculum was broadened and extended to include animal and physiological chemistry by the physicians William Babington and Alexander Marcet, ${ }^{2}$ the Quaker pharmacist William Allen, and chemists such as Arthur Aikin and John Bostock the younger. It was into this milieu that George Owen Rees came as a pupil in 1829 and it was here that he was to find encouragement for his interest in chemistry, which he was to maintain and develop throughout his long professional career.

Most of the founders of animal chemistry had cherished the hope that their studies would lead to the establishment of a new discipline within which improved methods of diagnosing, preventing, and curing diseases would be discovered. Thus, Antoine François Fourcroy in Paris, by his analyses of biliary and urinary calculi from about 1789 , heralded a fresh attack on this scourge of fashionable eighteenth-century life ${ }^{3}$ whilst Jöns Jacob Berzelius in Sweden improved analytical techniques to provide more reliable and complete information about the composition of animal fluids and

*Noel G. Coley, MSc, PhD, Staff Tutor in History of Science, The Open University, South East Region, 230-232 London Road, East Grinstead, W. Sussex RH19 1LA.

\footnotetext{
${ }^{1}$ Sometimes called 'king' Harrison, he had enormous influence over the development of Guy's Hospital and its services; S. Wilks and G. T. Bettany, Biographical history of Guy's Hospital, London, 1892, pp. 141-147 and passim; H. C. Cameron, Mr Guy's Hospital 1726-1948, London, 1954, pp. 106-109 and passim; G. T. Bettany in DNB, 1908, vol.9, p. 31; Wilfred J. Cripps (editor), Pedigree of the family of Harrison, [privately printed], 1881. A brief history of the medical school is given by T. B. Johnson in Guy's Hosp. Gaz., (commemorative issue), 1925, pp. 64-78.

${ }^{2}$ N. G. Coley, 'Alexander Marcet (1770-1822), physician and animal chemist', Med. Hist., 1968, 12: $394-402$.

${ }^{3}$ W. A. Smeaton, Fourcroy, chemist and revolutionary, 1755-1809, Cambridge, Heffer, 1962, pp. 136-162; John E. Lesch, The origins of experimental physiology and pharmacology in France 1790-1820: Bichat and Magendie, Ann Arbor, Mich., University Microfilms, 1979.
} 


\section{N. G. Coley}

tissues in health and disease. ${ }^{4}$ Amongst English physicians who contributed to the development of animal chemistry, William Prout was undoubtedly the most celebrated. ${ }^{5}$ Prout's work in animal analysis and the investigation of physiological processes predated that of Liebig and served to encourage others to pursue the medical applications of chemistry, notably Henry Bence-Jones ${ }^{6}$ at St George's Hospital, and Golding Bird ${ }^{7}$ and George Owen Rees ${ }^{8}$ at Guy's. However, these men were clearly exceptional, and within the early nineteenth-century medical profession there was very little interest in the aims and potential of animal chemistry. Those who sought to promote it met with indifference, if not hostility. Rees's work, carried out consistently and with meticulous care over a long period, was therefore important in helping to demonstrate the value of chemistry in medicine and overcome the apathy and resistance to its use within the profession.

Born at Smyrna (Izmir) in Turkey in 1813, the eldest son of a merchant of Welsh extraction and his Italian wife, Rees was educated in a small private school in the Clapham Road in London. He entered Guy's at the age of sixteen as a pupil of Richard Stocker, apothecary to the hospital, ${ }^{9}$ and quickly showed an inclination towards the chemistry laboratory as a relief from some of the less pleasant aspects of clinical practice. His ability in chemical analysis led to his being encouraged by Richard Bright and others to analyse samples of blood, urine, and other secretions in diseases of the kidney. From about 1833, he was a member of Bright's team of pupils and young physicians who were investigating every aspect of albuminuria. ${ }^{10}$ Two wards were set aside for the intensive study of renal disease under Bright's direction. A male ward of twenty-four beds was separated from a female ward of eighteen beds by a small room where physicians could meet to record and discuss cases, together

4Although Berzelius's textbook of animal chemistry, Forelasningar i Djurkemien, 2 vols., Stockholm, 1806-08, was never translated into English (see N. G. Coley, 'The Animal Chemistry Club; assistant society to the Royal Society', Notes Rec. R. Soc. Lond., 1967, 22: 173-185), his ideas on the subject were well known in England: see J. J. Berzelius, 'General views of the composition of animal fluids', Med-chir. Trans., 1812, 3: 198-276; idem, Ann. Phil., 1813, 2: 19-26, 195-208, 377-387, 415-425; and his presidential address to the Royal Swedish Academy of Sciences in 1810, J. J. Berzelius, $A$ view of the progress and present state of animal chemistry, trans. from Swedish by G. Brunmark, London, 1813 (2nd ed., 1818).

${ }^{5}$ W. H. Brock, 'The life and work of William Prout', Med. Hist., 1965, 9: 101-126; idem, in C. C. Gillispie (editor), Dictionary of Scientific Biography (DSB), 16 vols., New York, Charles Scribner's Sons, 1970-76, vol. 11 (1975), pp. 172-175; idem, From protyle to proton; William Prout and the nature of matter, 1785-1985, London, Adam Hilger, 1985.

${ }^{6}$ N. G. Coley, 'Henry Bence-Jones, M.D., F.R.S., (1813-73)', Notes Rec. R. Soc. Lond., 1973, 28: 31-56 (portr.).

'Idem, 'The collateral sciences in the work of Golding Bird (1814-54)', Med. Hist., 1969, 13: 363-376.

${ }^{8}$ There is no biography of Rees, but see obituaries by S. Wilks, Guy's Hosp. Rep., 1889, 46: xxiii-xxxiii; idem, Proc. R. Soc. Lond., 1889, 46: xi-xiii; W. W. Webb, DNB, 1908, vol. 16, pp. 842-843. See also, Lancet, 1889, i: 1282-1283; Br. med. J., 1889, i: 1383; W. Munk, Roll of the Royal College of Physicians, 7 vols, London, 1861-1985, vol. 4, 1955, p. 38; Wilks and Bettany, op. cit., note 1 above, pp. 251-261. I have been unable to find any unpublished papers relating to Rees's life or work.

${ }^{9}$ Stocker succeeded William Babington as apothecary at Guy's in 1795, his son James then held the post from 1834 for the next forty years; ibid., p. 410 .

${ }^{10}$ Bright sought to correlate clinical observations with the chemical analysis of body tissues and fluids and post-mortem examinations of the organs. Pamela Bright, Dr Richard Bright, 1789-1856, Oxford, Bodley Head, 1983, p. 220. See also, Lester S. King in DSB, vol. 2, 1970, p. 463; Steven J. Peitzman, 'Bright's Disease and Bright's generation: toward exact medicine at Guy's Hospital', Bull. Hist. Med., 1981, 55: 307-321. 
with a small laboratory fitted out specifically for the investigation of renal diseases. Microscopic and chemical examinations of tissues and secretions were made and correlated with clinical observations so that a complete pathological history of each case could be worked out. The chief object of this special unit-the first of its kind-was to recognize and identify those changes in the various functions and secretions of the body that accompany the appearance of albumin in the urine. It represents one of the earliest attempts to apply the physical sciences systematically to the study of a specific disease, and Rees was closely involved with all the chemical and microscopical aspects of the work. It was the school in which he received his practical training and inspiration. ${ }^{11}$ Rees himself recognized the importance of those early years and the debt he owed to Bright for " ... the kind encouragement received from you when as a mere boy I first entered upon the study of pathological chemistry." 12

Since the applications of chemistry to medicine were still relatively unexplored in the 1830 s, Rees and his colleagues were breaking new ground as they tried to correlate their chemical observations with the symptoms of particular diseases. Their work illustrated the truth of a claim made by Prout in 1816 that " ... Chemistry, ... in the hands of the physiologist, who knows how to avail himself of its means, will, doubtless, prove one of the most powerful instruments he can possess...."13 Rees, however, saw for chemistry a role which would extend far beyond the research laboratory; he wanted to bring simple chemical techniques within the reach of the ordinary medical practitioner. To this end he tried to establish reliable chemical tests which were quick, could be carried out with the minimum of facilities, and required no special manipulative skills. ${ }^{14}$ His approach was mostly a pragmatic one; he relied on so-called proximate analyses in the manner of Prout's early work and always saw his chemical results as a limited practical aid which, by supplementing traditional clinical methods, would lead to more reliable diagnoses. It is in this respect that Rees may be regarded as a pioneer. In this paper some contributions of his most active years (c. 1833-56) are discussed.

\section{EARLY WORK (1833-36)}

Already in 1833, whilst he was still a student, Rees showed conclusively that urea could be identified in the blood serum of diabetics. ${ }^{15}$ About the same time, he published an English translation of a small French manual of inorganic analysis

\footnotetext{
${ }^{11}$ Rees's contemporaries and successors in Bright's team included G. H. Barlow (1806-66); George Robinson (1821-75), and F. W. Pavy (1829-1911).

${ }^{12} \mathrm{G}$. O. Rees, On the analysis of the blood and urine in health and disease, London, Longmans, 1836. Quote from the dedication to Bright in the 2nd ed. (1845).

${ }^{13} \mathrm{~W}$. Prout, 'Inquiry into the origin and properties of the blood', Ann. Med. Surg., 1816, 1: 10-26, 133-157, 277-289.

${ }^{14}$ For example, G. O. Rees, 'On separating the phosphates of lime and magnesia in urinary calculi', Phil. Mag., 1833, NS. 2: 442 .

${ }^{15}$ Rees challenged remarks made by R. H. Brett and Golding Bird, Lond. med. Gaz., 1833, 12: 494-496, in which the presence of urea in diabetic blood serum was denied. G. O. Rees, 'On the presence of urea in the blood', ibid., p. 676. A controversy ensued in which Rees showed his grasp of chemical analysis, ibid., pp. 703-704, 765-766, 805-806, 863 .
} 


\section{N. G. Coley}

which had been compiled from Berzelius's works. ${ }^{16}$ Rees annotated his edition with practical hints on working, which made it a useful laboratory guide for students and an excellent companion to Berzelius's other little treatise on the blowpipe. ${ }^{17}$ It contained the Swedish chemist's rules for analysing gases, a large number of salts, and many common mineral waters, using well-known reagents and simple gravimetric procedures. The importance of analysis in chemistry teaching was emphasized by Rees, who wrote, "I am certain that nothing so far tends to impress the great laws of chemistry on the mind as an acquaintance with the minute changes and reactions occurring in the course of a careful analysis...."18

Recognizing that such minute changes were nowhere more important than in animal chemistry as applied to medicine, Rees went on to publish a short treatise on the analysis of the blood and urine.$^{19}$ In his efforts to underline the need for improved reliability, he began by taking the suppliers of common chemical reagents to task on the question of contamination with impurities which would interfere with the analytical results. His opinion of the chemical purity of the materials sold by the average chemist and druggist in London in the 1830s was very low indeed: “. . . the existence of such a body as the untaught tradesmen who arrogate to themselves the title of chemist, remains one of the most amusing absurdities of the nineteenth century." ${ }^{20}$ Their distilled water, he said, often contained chlorides; their muriatic (hydrochloric) acid always contained iron and often sulphuric acid, which was also present in the nitric acid they sold. Sulphuric acid itself often contained arsenic and usually also lead, whilst the official liquor potassae generally contained lime. Consequently, "... this, as well as every other solution intended for the use of the laboratory, should be such as has never had a place in the shops of any ordinary chemist and druggist of this city."21

Whilst Rees based his analyses on Berzelius's work, he was aware that others had also applied chemical methods to the analysis of the blood, especially Lecanu, who had introduced the name haematosine for the red colouring matter of blood. ${ }^{22}$ Rees suggested that the composition of healthy blood should first be determined so that it could be used as a comparative guide in cases of disease which resulted in noticeable changes. He remarked that in cholera, for instance, the blood contains less water, whilst in diabetes there is an excess of fatty matter, as well as urea. Other foreign

${ }^{16} \mathrm{~J}$. J. Berzelius, The analysis of inorganic bodies, trans. from Esslinger's French edition (1827) by G. O. Rees, London, Longmans, 1833. The book was praised as a contribution to the teaching of chemical analysis, Lond. med. Gaz., 1833, 12: 181. Rees's uncle, Owen Rees (1770-1837), was a partner in Longmans from 1797 to 1837; Asa Briggs (editor), Essays in the history of publishing in celebration of the 250th anniversary of the House of Longman, 1724-1974, London, Longmans, 1974, p. 8.

${ }^{17} \mathrm{~J}$. J. Berzelius, The use of the blowpipe in chemical analysis and in the examination of minerals, trans. from Fresnel's French edition by J. G. Children, London, 1822.

${ }^{18}$ Rees, op. cit., note 16 above, introduction.

${ }^{19}$ Rees, op. cit., note 12 above.

${ }^{20}$ Ibid., p. 10 . Prout also commented unfavourably on the purity of available reagents; W. Prout, 'Observations on the nature of some of the proximate principles of the urine', Med-chir. Trans., 1817, 8: 526-549. The rise of the chemical profession is discussed in C. A. Russell, N. G. Coley, and G. K. Roberts, Chemists by profession, Milton Keynes, Open University Press and Royal Institute of Chemistry, 1977, pp. 44-50.

${ }^{21}$ Rees, op. cit., note 12 above, p. 10.

${ }^{22}$ L. R. Lecanu, Etudes chimiques sur le sang humain, Paris, 1837; idem, Ann Chim., 1838, 67: 54-70. Lecanu's analysis of the blood was frequently quoted in contemporary works on physiology. 
matters sometimes found in the blood included the colouring matter of the bile, cholesterine, and even free carbon, but due to inadequate analytical methods these substances had either been confused with others or missed altogether. Before the 1830 s, much less attention had been paid to the composition of body fluids than to the solid parts, and in turning attention to the analysis of the blood and urine in their diseased as well as their healthy states, Rees was opening up a relatively uncharted area of pathological chemistry. ${ }^{23}$ In his analysis of blood serum he emphasized the need to determine the proportions of each constituent by a separate procedure, and attributed earlier failures to detect urea in diabetic blood to the desire to determine all the constituents by a single analysis. ${ }^{24}$

In his analysis, of the urine, Rees used Berzelius's method for the determination of lithic (uric) $a \mathrm{acid}^{25}$ and Prout's method for urea.$^{26}$ Although he quoted Berzelius's detailed figures for the quantitative analysis of the urine, he realized that the Swedish chemist's methods required considerable analytical skill. For the purposes of the average practitioner, therefore, Rees proposed a much simpler scheme which would yield just six fractions as a sufficient guide to diagnosis. ${ }^{27}$ Nevertheless, he recognized the need for reliable figures for the quantitative analysis of healthy urine to provide comparisons with the results obtained from diseased specimens. ${ }^{28}$ Naturally, Bright's disease was the condition that most directly concerned Rees, and this led him to investigate the methods available for detecting albumin in the urine. Two simple procedures were in common use, viz., the addition of strong nitric acid, and heating to the boiling point, both of which yield a precipitate. Unfortunately, there are several conditions in addition to albuminuria that give similar results, and it is not always easy to identify the precipitate genuinely due to albumin. It was known, for instance, that a deposit of earthy phosphates might be formed on heating, though this would dissolve in dilute nitric acid. Rees therefore advocated the use of both tests. ${ }^{29}$ However, other complicating factors led him to return to the problem on several later occasions, ultimately developing a comprehensive method for the identification of albumin, which involved the use of potassium ferrocyanide and mercury perchloride as well as the traditional tests.

\section{GROWING RECOGNITION (1837-47)}

Rees was awarded the MD by Glasgow University in April 1837, and, soon afterwards, he was asked to write part of a report on animal analysis following the British Association meetings of that year. ${ }^{30}$ The report dealt with the analysis of

\footnotetext{
${ }^{23}$ The partial views taken by both humoral pathologists and "solidists" were criticized in William Stevens, Observations on the healthy and diseased properties of the blood, London, 1832, preface p. ix.

${ }^{24}$ Rees, op. cit., note 12 above, p. 41.

${ }^{25} \mathrm{~J}$. J. Berzelius, 'General views of the composition of animal fluids', Med-chir. Trans., 1812, 3: 198-276, see p. 270; idem, Ann Phil., 1813, 2: 19-26, 195-208, 377-387, 415-425.

${ }^{26}$ Prout, loc. cit., note 20 above.

${ }^{27}$ Rees, op. cit., note 12 above, p. 64.

${ }^{28}$ Ibid., p. 71. Diseased urine had been frequently examined in connexion with cases of bladder stone; H. Ellis, $A$ history of bladder stone, Oxford, Blackwells, 1969; N. G. Coley, 'Animal chemists and the urinary stone', Ambix, 1971, 18: 69-93.

${ }^{29}$ Rees, op. cit., note 12 above, p. 83.

${ }^{30} \mathrm{Idem}$, 'Report from the Committee for inquiring into the Analysis of the Glands of the Human Body', Brit. Assoc. Rep., 1837, 7: 149-154.
} 


\section{N. G. Coley}

human glands, for which Rees proposed a programme of research to compare the composition of these organs in health and disease. As before, he did not attempt complete analyses as Berzelius had done, but merely suggested a scheme by which broad comparisons could be made which would be of value to the physician. The basis of his suggestion was to consider all the organs as derived from the blood and therefore susceptible to the same general techniques of analysis. Then, since diseased organs would show an increase, decrease, or total absence of certain normal constituents, or the presence of some foreign matter, chemical analysis could be used to confirm clinical observations. In keeping with his ideas about the utility of animal extractives, Rees proposed to treat samples of glands and organs with a series of solvents using ether, alcohol, and water. He considered that each healthy gland and organ would yield a characteristic group of identifiable extractives by means of which standards of comparison could be established. Many workers all using the same "rule of analysis" could then build up a stock of results for comparison in each new case. Although these suggestions were not pursued by others, Rees himself made use of similar comparative methods which he applied to the relationships between the chemical composition of organs, secretions, and ingesta.

In 1838, Rees described a method for isolating sugar from the blood serum of diabetics, which has been hailed as his first major contribution to medical chemistry. ${ }^{31}$ His objective was to separate sugar crystals from diabetic blood serum by a quicker and simpler process than the only previously successful one, which took several weeks to complete. Rees's method, which yielded crystals of diabetic sugar, could be completed within two days. It involved extractions with boiling water, alcohol, and ether, interspersed with filtration and evaporation to dryness and he attributed its success to the use of ether, which removed urea and fatty matter. In view of his earlier criticisms, it is interesting that he could now say, "I find the ether of the shops of s.g.0.754 which, of course contains some alcohol in its composition, is an active solvent of urea, while it exerts no action on the diabetic sugar." 32

In common with other animal chemists, notably Prout, Rees was also interested in the relationships between chyle, lymph, and blood, and in the roles of each of these in metabolism. He found during some experiments on the chyle of the ass that in the process of digestion the proportion of albuminous matter fell and the fats were almost entirely removed as it was converted into lymph. The latter contained more water and water-soluble matter than the chyle, but an aqueous extract of chyle contained iron, which was absent from the same extract of lymph. From these results, he agreed with those who thought that chyle was an intermediate stage in the formation of blood. ${ }^{33}$ Typically, Rees had made his analyses of chyle and lymph at the request of a colleague, Samuel Lane, who had been commissioned to supply articles on these topics for Todd's Cyclopaedia of anatomy and physiology. ${ }^{34}$ Rees later

\footnotetext{
${ }^{31}$ Idem, 'On diabetic blood', Guy's Hosp. Rep., 1838, 3: 398-400. This paper is one of three by Rees quoted in William B. Ober (editor), Great men of Guy's, Metuchen, NJ, Scarecrow Reprint Corporation, 1973, pp. xix, 237-258. The presence of sugar in diabetic blood had previously been doubted.

${ }^{32}$ Idem, loc. cit., note 31 above, p. 400.

${ }^{33}$ Idem, 'Analysis of chyle and lymph', Phil. Mag., 1841, 18: 156-157;idem, Lond. med. Gaz., 1840-41, NS. 1: $547-549$.
} 
supplied other articles in his own right over a number of years until the completion of the work in 1859. Many of these were to remain as the standard information on their subjects throughout most of the nineteenth century. ${ }^{35}$

Rees and Lane were also working together at about the same time on the physical and microscopical structure of the blood. ${ }^{36}$ The most recent survey of current knowledge on the nature and functions of the blood had been given by the surgeon Henry Ancell in a lecture series at the School of Anatomy near St George's Hospital, London, but, although Ancell's lectures were comprehensive, they did not bring forward any new ideas. He did, however, acknowledge that Lane had demonstrated to him the existence of a membrane surrounding each red corpuscle. ${ }^{37}$ In their new studies of the blood, Lane and Rees investigated the osmotic effects caused by various salt solutions at different dilutions, basing their explanations of these effects on the work of Dutrochet. ${ }^{38}$

Two years later, Rees returned to his studies of the blood when G. H. Barlow published a long account of the observations of members of Bright's team on patients suffering from albuminuria. Rees was asked to supply quantitative analyses of body fluids, including blood serum, urine, and fluids of the ventricles of the brain, pleura, and peritoneum. ${ }^{39}$ Although the total space allotted to these analyses was small in comparison with the rest of the paper, Rees's numerical results provided essential diagnostic data. They also spurred him to develop his own ideas further. He chose six of the cases and used them as the basis for a brief study of the relationships between the chemical properties and corpuscular structure of the blood. ${ }^{40}$ In order to examine the red colouring matter of the blood, he first separated the red corpuscles and then placed them in water so that by endosmosis they would swell up until they burst, releasing the colouring matter into aqueous solution. By using various salt solutions at different dilutions, he concluded that a solution whose specific gravity was equal to that of healthy blood serum would leave the red corpuscles unchanged-an early recognition of the concept of a normal saline solution.

Rees also continued his experiments on the relationship between chyle and blood and, at the suggestion of his friend P. M. Roget, he read a paper to the Royal Society

\footnotetext{
${ }^{34}$ S. Lane, 'Lymphatic and lacteal system', in Robert Todd, Cyclopaedia of anatomy and physiology, 5 vols., London, 1835-59, vol. 3, p. 205-232 (Rees’ analyses p. 223).

${ }^{35}$ In the section headed 'Animal Chemistry', Rees has seven entries, viz., Haematosine, vol. 2, pp. 503-504; Milk, vol. 3, pp. 358-363; Mucus, vol. 3, pp. 481-484; Saliva, vol. 4, pt. 1, pp. 415-422; Sweat, vol. 4, pt. 2, pp. 841-845; Synovia, ibid., p. 856; Urine, ibid, pp. 1268-1294.

${ }^{36} \mathrm{G}$. O. Rees and S. Lane, 'On the structure of the blood corpuscle', Guy's Hosp. Rep., 1841, 6: 379-391.

${ }^{37} \mathrm{H}$. Ancell, 'Course of lectures on the physiology and pathology of the blood and other animal fluids', Lancet, 1839-40, i: 41-50, 145-154, 222-230, 307-316, 377-385, 457-464, 521-529, 601-609, 681-687, 745-752, 825-830, 905-913; ii: 1-8, 65-74, 149-157, 257-264, 439-445, 548-556, 661-671, 739-749, 772, 836-844, 886-894, 916-922.

${ }^{38} \mathrm{H}$. Dutrochet, 'Nouvelles observations sur l'endosmose et l'exosmose et sur la cause de ce double phénomène', Ann. Chim., 1822, 35: 393-400; 1828, 37: 191-207; 1832, 49: 411-437; 1832, 51: $159-166$.

${ }^{39} \mathrm{G}$. H. Barlow, 'Account of observations made under the superintendance of Dr. Bright on patients whose urine was albuminous ...', Guy's Hosp. Rep., 1843, 8: 189-316 (9 plates). Rees' analyses are on pp. 192, 196, 204, 215, 239, 259, 266, 287, and 290.

${ }^{40} \mathrm{G}$. O. Rees, 'Observations on the blood with reference to its peculiar condition in cases of morbus Brightii’, ibid., 1843, 8: 317-330.
} 


\section{N. G. Coley}

in 1842 in which he described analyses of the contents of the human thoracic duct. ${ }^{41}$ The material for this work was obtained from newly executed criminals, and care was taken in extracting the chyle to see that no serous secretion or blood corpuscles became mixed with it. Rees found that the fatty matter of the chyle was similar to that of blood, except that the latter contained phosphorus, and this observation was to form the starting-point for a new theory of respiration which he proposed five years later. In 1842, however, he took up again the idea that chyle was an intermediate product in the formation of blood. By this time, he had become suspicious of the claim made by some that the incipient reddening of chyle as it changed into blood could be observed. Even the great German physiologist, Johann Müller, stated that he had observed this change in the horse, ${ }^{42}$ but Rees by his careful experiments had failed to confirm it, and he wrote, "My own observations do not agree with this statement; for fluid taken from the thoracic duct of the dog, ass and cat as also that lately obtained from the human subject, showed no such colour when under the conditions stated by Müller . ..."43 He agreed that there might sometimes be a few red corpuscles in samples of chyle, but he thought it most likely that these had found their way into the chyle during the surgical operations needed to remove it from the body.

In addition to his chemical analysis of chyle, Rees also examined its appearance under the microscope, and this led him to remark that there seemed to be no difference between samples of chyle taken from carnivores and herbivores. Even animals fed entirely on beans and oats-very different from fats-produced chyle containing a large proportion of fatty globules. Indeed, the corpuscles observed in both forms of chyle were the same. It was commonly thought that this fatty matter was merely oxidized to carbon dioxide and water, which were excreted by the lungs and skin, but Rees inclined to a different view. He suggested that the fatty matter reacted with nitrogen as well as oxygen during respiration and so was converted into albumin, which then took part in nutrition. Although he was unable to confirm this view, Rees's paper was regarded as a useful addition to animal chemistry, and it led to his election to the Fellowship of the Royal Society. ${ }^{44}$ It also brought him to the notice of Sir Benjamin Brodie, who secured for him the post of physician to the new Pentonville prison. Here, over many years, Rees was concerned with questions of hygiene, diet, clothing, exercise, and the effects of solitary confinement on the prisoners.

Throughout his career, Rees always placed more reliance on his own chemical observations than on the pronouncements of others, no matter how illustrious - his criticism of Müller has already been mentioned. In 1839, he denied the presence of fluorides in bone, ivory, tooth enamel, and urine, and thus directly challenged

\footnotetext{
${ }^{41}$ Idem, 'On the chemical analysis of the contents of the thoracic duct in the human subject', Phil. Trans. R. Soc. Lond., 1842, 132: 81-85.

$42 \mathrm{~J}$. Müller, Elements of physiology, trans. W. Baly, 2 vols., Philadelphia, 1838-42, vol. 1 (1838), p. 561. Prout also thought that chyle was converted into blood either in the lungs or the arteries; W. Prout, 'On the phenomena of sanguification and on the blood in general', Ann Phil., 1819, 13: 12-25, 265-279.

${ }^{43}$ Rees op. cit., note 41 above, p. 84.

${ }^{44}$ On 2 February 1843 . He was introduced to the Society by its Foreign Secretary, P. M. Roget, and his certificate of election was signed by W. Prout, B. C. Brodie, R. Bright, J. Bostock, W. T. Brande, T. Graham, and R. Phillips, amongst others.
} 
Berzelius's results of 1807 , which had been generally accepted by chemists..$^{45}$ In explanation, Rees pointed out that phosphoric acid when volatilized by heat will attack poor-quality glass in a way that may be confused with the action of hydrofluoric acid. Two years later, he investigated the claim made by M. J. B. Orfila, professor of forensic medicine and toxicology in Paris, that arsenic occurs naturally in human bones. ${ }^{46}$ Rees pointed out that this was an extremely important issue for the medico-legal chemist, for, if it were true, it would be hard to imagine any murder case involving arsenic in which the accused would not be acquitted.

Orfila had incinerated bones, digested the ash with strong sulphuric acid, and then, after diluting the mixture and filtering, had carried out Marsh's test on the remaining solution. Rees repeated these procedures on large quantities of bones without ever obtaining an arsenic mirror and he therefore looked for some explanation of Orfila's claim. In some of the experiments the glass became encrusted with a white solid that looked like arsenious oxide, though it proved to be calcium phosphate. When treated with silver nitrate and then exposed to ammonia, this white solid turned yellow due to silver phosphate, a reaction precisely similar to that given by an arsenite. Another possible source of error came from the fact that if the hydrogen used in Marsh's test were evolved too rapidly, a deposit of zinc sulphate might be formed. If this is dissolved in water and ammoniacal silver nitrate added, a cloudy precipitate of zinc hydroxide will be produced which might be confused for a small quantity of silver arsenite. Again, if porcelain glazed with lead is used to collect the arsenic mirror, the flame may reduce the lead and produce a dark metallic stain, which might be confused for arsenic. In addition, Rees was aware, as we have already noted, that chemical reagents may be contaminated, and in particular both sulphuric acid and zinc may contain arsenic as an impurity. In his own experiments he was careful to avoid this source of error, but he wondered whether there might not have been arsenic either in the reagents or in the apparatus used by Orfila. Since he could find no arsenic in human bones by any of the tests he employed, Rees concluded that Orfila was probably wrong: ${ }^{47}$ " ... for I must confess, notwithstanding my high estimation and respect for him as a medico-legal chemist, ... I could not resist the conclusion, that his great fame as a philosopher had betrayed him into something like boldness on the one hand, and carelessness on the other."48

As a result of his extensive analytical work on human organs and tissues, Rees was frequently requested to supply analyses for legal purposes by his colleague Alfred Swaine Taylor, the first professor of medical jurisprudence at Guy's. ${ }^{49}$ The thoroughness and reliability of Rees's results made them eminently suitable for use

${ }^{45} \mathrm{G}$. O. Rees, 'On the supposed existence of fluoric acid as an ingredient in certain animal matters', Guy's Hosp. Rep., 1839, 4: 381-384.

${ }^{46}$ M. J. B. Orfila, Recherches médico-légales et thérapeutiques sur l'empoisonnement par l'acide arsénieux, Paris, 1842, pp. 96-102.

${ }^{47} \mathrm{G}$. O. Rees, 'On the existence of arsenic as a natural constituent of human bones', Guy's Hosp. Rep., 1841, 6: 162-171. According to A. S. Taylor, Orfila had already withdrawn his opinion about the presence of arsenic in the human body in 1841 ; A. S. Taylor, 'Trial for murder by poisoning with arsenic ...., ibid., 1845, 2nd ser., 3: 194.

${ }^{48}$ Rees, op. cit., note 47 above, p. 164.

${ }^{49}$ For obituaries of A. S. Taylor see, W. W. Webb in DNB, 1908, vol. 19, pp. 402-403; Lancet, 1880, i: $897 ; B r$. med. J., 1880, i: 905-906. 


\section{N. G. Coley}

in court, and most of the analyses used by Taylor in preparing his evidence as an "expert witness" had been carried out either by Rees alone or in collaboration with Taylor. Their joint work came prominently before the public in 1856 during the trial of William Palmer, the "Rugeley poisoner". 50 Taylor and Rees were called to give evidence on the cause of death, and their findings were confirmed and supported by a number of other prominent chemists, including William Brande of the Royal Institution and Sir Robert Christison, professor of medical jurisprudence at Edinburgh. Palmer was found guilty of poisoning by strychnine. Rees was already well-known within the medical profession, and his connexion with this famous trial brought his name before a wider public.

"THE FALLACY OF THEORIES"

In the 1830 s when Rees began his career, the utility of chemistry in medicine was just coming to be recognized. Chemical explanations were in fashion and when Thomas Hodgkin introduced the report of the Medical Section of the British Association for the Advancement of Science in 1837, he stated that its Committee had sought " ... to obtain through the medium of animal chemistry in its present improved state, some further insight into the mysterious and vital process of secretion." 51 For some time, animal chemistry lived up to its early promise, and by 1845 , in the second edition of his book on the analysis of blood and urine, Rees was forced to make numerous alterations as a result of the advances that had occurred in the nine years which had elapsed since the first edition. These were just beginning to produce some of the expected improvements in pathology and were gradually overcoming traditional resistance to the utility of chemistry in medicine. ${ }^{52}$ Urine analysis had achieved some recognition as a valuable adjunct to clinical observations, but in Rees's view chemistry was not yet capable of supplying detailed information about the sequence of changes occurring in natural functions, nor could it suggest appropriate modes of medical treatment. He was very sceptical about the value of speculative theories, which he thought did more harm than good, for when they were shown to be incorrect or inadequate chemistry could then be " . . the more eagerly condemned as useless". ${ }^{53} \mathrm{He}$ asserted that whilst chemistry had yielded insights into the pathology of certain diseases such as diabetes, calculus, and Bright's disease, these were firmly based upon experimental observations and in no way dependent upon theories of metabolism. In his article on the urine in the Cyclopaedia of anatomy and physiology, Rees expressed his deep distrust of Liebig's ideas about the metabolic changes leading to the chemical composition of the urine.

\footnotetext{
${ }^{50}$ For a description of the trial of William Palmer see Leonard A. Parry, Some famous medical trials, London, 1927, pp. 235-258. It was fully reported in The Times, 14 May 1856, et seq.; Lancet, 'The scientific evidence on the trial of William Palmer', 1856, i: 563-586, 596-613; the Illustrated Times devoted the whole issue of 2 February 1856 to the events leading up to the Rugeley murders and the inquest on J. P. Cook. A significant outcome of the trial was a reappraisal of the whole field of life assurance, since Palmer had stood to benefit financially in several cases of death in somewhat suspicious circumstances of persons close to him, including his own wife.

${ }^{51} \mathrm{~T}$. Hodgkin, 'Provisional report of the Committee of the Medical Section of the British Association appointed to investigate the composition of the secretions and the organs producing them', Brit. Assoc. Rep., 1837, 7: 139-148, see p. 139.

${ }^{52}$ Rees, op. cit., note 12 above, p. 39.

${ }^{53}$ Idem, in Todd, op. cit., note 34 above, vol. 4, pt. 2, p. 1282.
} 


\title{
George Owen Rees, MD, FRS (1813-89)
}

\begin{abstract}
Liebig has theorized freely on this subject, and it is but right that what he has published should be copied into this article, if only as part of the history of the urine, while I would warn the reader carefully to separate in his mind the matter of fact from the theoretical part of the subject, inasmuch as a great deal yet remains to be done. The position of the inquiry is indeed at present such that further advances may very probably lead us to detect the fallacy of theories which it is to be feared, the present state of our knowledge may permit us to see in too attractive a form. ${ }^{54}$
\end{abstract}

This view stands in stark contrast to that of some of his contemporaries, notably Henry Bence-Jones, who had studied briefly under Liebig at Giessen and had become so impressed by Liebig's system of oxidative metabolism that he had used it as the basis of his own work in animal chemistry. ${ }^{55}$ Bence-Jones's aim was to identify the causes of disease in faulty metabolism and to suggest means of correcting such faults at their source. The study fell more naturally into the field of animal chemistry than that of medicine, and it was to develop later in the century into the complex science of biochemistry. On the other hand, Rees's work made a significant contribution to early clinical chemistry. He had entered the field not in the heady atmosphere of Liebig's research school, but through the busy wards of Guy's Hospital, where he was daily confronted with urgent medical problems which required specific, practical solutions. His objectives were therefore much more limited and his chemical work was related to the physiological chemistry of J. F. Simon, ${ }^{56}$ J. J. von Scherer, ${ }^{57}$ C. G. Lehmann, ${ }^{58}$ and others in Germany. Rees commented critically on their work and drew upon some of their results, especially in his Croonian Lectures on calculous disorders. ${ }^{59}$ As a physician, he realized the need to make chemical tests both simple and reliable, and it was his success in combining these two objectives that gradually persuaded his more sceptical colleagues of the value and utility of medical chemistry.

\footnotetext{
${ }^{54}$ Ibid., p. 1272.

${ }^{55} \mathrm{H}$. Bence-Jones, On gravel, calculus and gout: chiefly an application of Prof. Liebig's physiology to the prevention and cure of these diseases, London, 1842.

${ }^{58}$ Johann Franz Simon (1807-43) became a private tutor in the University of Berlin in 1843, but his death later that year cut short his career. He wrote a handbook of practical toxicology and an account of European mineral springs with particular reference to their chemical composition. J. C. Poggendorff, Biographisches-literarisches Handwortenbuch zur Geschichte der exacten Naturwissenschaften, Leipzig, 1863- , vol. 2, p. 936. Simon's Handbuch der medizinischen Chemie, Leipzig, 1840-42, appeared in English as Animal chemistry with reference to the physiology and pathology of man, trans. by George E. Day, 2 vols., London, 1845-46.

${ }^{57}$ Johann Joseph Scherer (1814-69) practised medicine from 1836 to 1841, after which he spent eighteen months working in Liebig's laboratory at Geissen. He then moved to the University of Würzburg, where he was in charge of the medical chemistry laboratories. He wrote on the applications of chemistry and microscopy to pathology. Poggendorff, op. cit., note 56 above, vol. 2, p. 790; J. Büttner, 'Johann Joseph Scherer (1814-69). Ein Beitrag zur frühen Geschichte der klinische Chemie', J. clin. Chem. clin. Biochem., 1978, 16: 478-483.

${ }^{58}$ Carl Gotthelf Lehmann (1812-63) was professor of physiology at Leipzig, where he wrote his Lehrbuch der physiologischen Chemie, 3 vols., Leipzig, 1842-45, (English trans., Physiological Chemistry, trans. by Geo. E. Day, 3 vols., 1848; 2nd ed., 1851; 3rd ed., 1853). His chief work was on the chemistry of the urine and blood. Poggendorff, op. cit., note 56 above, vol. 1, pp. 1411-1412; A. W. Hofmann, J. Chem. Soc., 1863, 16: 433-434.

${ }^{59} \mathrm{G}$. O. Rees, On calculous disease and its consequences, being the Croonian Lectures for the year 1856 delivered before the Royal College of Physicians, London, 1856. Rees, who had assisted Brodie in the analysis of urinary stones, relied upon B. C. Brodie, Lectures on the diseases of the urinary organs, London, 1832 (4th ed., 1849).
} 


\section{N. G. Coley}

Nevertheless, critical as he was of theoretical speculation, Rees was not always able to resist the temptation to erect a theory on the basis of his observations. Thus, when, in 1847, he submitted a second paper to the Royal Society, in which he discussed the functions of the red blood corpuscles during the process of arterialization, he proposed a new theory to explain the changes he had observed. ${ }^{60}$ Having noticed a garlic-like odour reminiscent of phosphorus when the crassamentum of venous blood was shaken up with distilled water, he proceeded to investigate the fate of phosphorus in the blood. Taking separate portions of the same venous blood, he exposed one to the air to oxidize, or "arterialize", it. On analysis, it was found that the serum of the oxidized sample contained a higher proportion of tribasic sodium phosphate, and Rees explained this by saying that the fats in venous blood contain phosphorus which is oxidized to phosphoric acid during arterialization. This then combines with alkali in the liquor sanguinis, forming tribasic sodium phosphate, which acts upon haematosine to produce the familiar bright colour of arterial blood and is thus removed from the serum. The tests on which he based this conclusion were delicate and the conditions critical. If correct, the theory seemed to imply that nearly all the alkaline phosphates formed in arterial blood must be discharged from it before it reached the veins, and, considering the rapidity of the circulation, this would necessitate a large and constant supply of phosphorus to the venous blood as well as a more copious elimination of phosphoric acid than had hitherto been suspected. Before the paper could be accepted for publication more evidence was demanded, and Rees set out to test his theory further, but, though he produced more qualitative results which seemed to support it, he was unable to demonstrate its truth beyond doubt. It is perhaps ironic that the simple tests and elementary chemical notions that had served him so well in other aspects of medical chemistry, including his investigations of the blood, should fail him as he tried to unravel the complex reactions involved in one of its chief functions. ${ }^{61}$

\section{CONTRIBUTIONS TO URINE ANALYSIS (1850-56)}

By the 1850s, Rees had become one of the leading authorities on medical chemistry in England, but he never lost sight of his primary objective to improve diagnosis and treatment. He was noted for his skill in interpreting microscopic observations and for the reliability of his chemical analyses for which his services were often in demand, but it is in his work on the chemistry of the urine that he is seen at his best. In 1850, he published a practical treatise on the nature and treatment of kidney diseases connected with albuminuria, which aimed to bring the chief results of his work as a member of Richard Bright's team within reach of the ordinary medical practitioner. ${ }^{62}$ Recognizing that the same symptoms could be produced by different causes, he identified at least five conditions besides Bright's disease which could

\footnotetext{
${ }^{60} \mathrm{G}$. O. Rees, 'On the function of the red corpuscles of the blood and on the process of arterialization', Proc. R. Soc. Lond., 1843-50, 5: 677-678. The paper was read at a meeting of the Royal Society on 3 June 1847 , but was withheld from publication to await more convincing experimental evidence.

${ }^{61}$ Idem, Phil. Mag., 1848, 2nd ser. 33: 28-35; Erdmanns J. Prak. Chem., 1849, 46: 129-137.

${ }^{62}$ Idem, On the nature and treatment of diseases of the kidney connected with albuminous urine (Morbus Brightii), London, 1850. Rees's tests for albumin in urine are summarized on pp. $30 \mathrm{f}$.
} 
result in the secretion of albuminous urine. Though they were only minor or temporary, these conditions were all capable of confusing the unwary doctor, and Rees showed how unimportant symptoms could be dismissed and the serious causes of albumin in the urine identified. Rees considered that as a result of "The application of a more correct chemistry ... the subject [i.e. urine analysis] is now less frequently confused by albumen [sic] being declared present when such is not the case; and on the other hand, when it may be present, it is less likely to be overlooked than formerly ...."63 Indeed, the enhanced regard in which chemistry in general and urine analysis in particular had come to be held within the medical profession by the middle of the century is reflected in the view expressed by the surgeon Bransby Cooper that, “. . . in the present state of pathological knowledge, no medical practitioner should consider himself competent to undertake the treatment of urinary diseases who is not able to investigate the chemistry characters of abnormal urine ...."64 In Rees's view, this was precisely the role that chemistry could properly fill.

Turning to the available chemical tests for albumin, Rees showed how it was possible to identify this compound in the presence of other substances that might interfere and confuse the result. Thus, if urates were present in the urine, uric acid would be precipitated by the nitric acid and this might be mistaken for albumin unless another sample of the urine were tested with hydrochloric acid, which also precipitates uric acid but not albumin. Another possible source of confusion arose when patients were being treated with certain vegetable substances such as copaiba or cubebs. ${ }^{65}$ In these cases, the nitric acid would produce a cloudiness in the urine sample, which might be mistaken for albumin. Rees reminded his readers that there were also simple ways of avoiding this error, since the cloudiness does not subside as the albumin precipitate does, and a mixture of potassium ferrocyanide and acetic acid will not produce it, although the same mixture does precipitate albumin. Lastly, calcium phosphate may also cause confusion because, like albumin, it is precipitated on heating the urine sample. In this case, however, a drop of nitric acid would dissolve the precipitate. By these and similar observations, Rees showed how simple chemical tests could improve the reliability of diagnoses.

In the following year, he further expounded his views on urine analysis in his Lettsomian lectures at the Royal Society of Medicine. ${ }^{66} \mathrm{He}$ began by reiterating the importance of chemical and microscopical observations as well as their limitations in diagnosis. These new methods, he said, should neither be isolated from, nor thought to supersede older clinical traditions, but should be integrated with them. In the first of his three lectures, Rees turned his attention to the phenomena and causes of alkaline urine. Superficially, it had long seemed that this condition could be rectified

${ }^{63}$ Ibid., p.1.

${ }^{64} \mathrm{~B}$. B. Cooper, 'On the application of chemical analysis and microscopic examination of morbid products to the formation of a correct diagnosis', Guy's Hosp. Rep., 1851, 2nd ser. 7: 101-123, see p. 110.

${ }^{65} \mathrm{G}$. O. Rees, 'On the detection of albumen [sic] in the urine', Lond. med. Gaz., 1840-41, NS. 1: 438-440; idem, 'Observations on real and supposed pathological conditions of the urine', Guy's Hosp. Rep., 1841, 6: 121-130.

${ }^{68}$ Idem, 'On some pathological conditions of the urine', Lond. med. Gaz., 1851, NS. 13: 29-37, 45-49, 133-138. 


\section{N. G. Coley}

by simple chemical means (i.e. by prescribing acidic solutions), but Rees declared that this was not necessarily true, since any treatment must take into account the underlying causes of the disorder. Thus alkaline urine occurred in diseases of the spine, in dyspepsia, the ingestion of medicines or food containing alkaline salts, and as a result of the irritation of the urinary mucous membranes. Rees noted that Prout had mentioned another cause, viz., the discharge of an excess of soda, potash, or ammonia from constitutional causes, but he denied this and instead related the condition to disease of the mucous surfaces of the bladder. ${ }^{67}$ Following Berzelius and Liebig, Rees ascribed the acidity of the gastric juice to lactic and phosphoric acids ${ }^{68}$ and held that the proportions of their salts in the urine could be taken as an indicator of the state of health of the patient. ${ }^{69}$

Rees had earlier noted that when albumin was present in the urine there was a marked decrease of albumin in the blood. The liquor sanguinis became watery and secondary conditions developed, of which the most important was the appearance of urea. He was not sure how such changes came about, but his studies of Bright's disease had convinced him that they were related to malfunctions of the kidney. Clinical observations had also shown that loss of albumin from the blood was connected with anaemia, but the quantity of albumin present in the urine decreased with time and in some advanced cases it ceased altogether. ${ }^{70}$ Thus readily identifiable changes in the chemical composition of the blood and urine could be correlated with well-known pathological conditions.

In his Lettsomian lectures, Rees described his efforts to test whether in some diseases extractives and salts of the blood may be effused and appear in the urine without albumin. He had found that albuminous urine always gave a positive test with galls, and he looked for similar reactions in other cases. He found that in debility, anasarca and heart disease, chlorotic anaemia and hysteria extractives of the blood were commonly present in the urine without albumin. In anaemia, he noted that the quantity of such extractives decreased as the iron treatment for the disease began to take effect, and in general the concentration of such substances in the urine was usually greater in the early stages of disease, before physical symptoms had become manifest. Thus chemical analysis could alert the physician to the onset of disease and open up a whole new aspect of medical diagnosis by providing evidence of otherwise unobservable and previously unsuspected symptoms in the early stages of disease whilst the prospects of successful treatment were still good. The small number of cases then investigated counselled caution, but Rees said, "I think, however, we may safely state that we have proved beyond a doubt that in certain diseased conditions an important drain upon the blood is going on of which we have been totally ignorant up to the present time." ${ }^{71}$ Chemistry, it seemed, could

\footnotetext{
${ }^{67}$ Ibid., p. 30 .

${ }^{68}$ It seems surprising that Rees should have ignored Prout's discovery of hydrochloric acid in gastric juice. W. Prout, 'On the nature of the acid and saline matters usually existing in the stomachs of animals (1823)', Phil. Trans. R. Soc. Lond., 1824, 114: 45-49.

${ }^{69}$ Bence-Jones was also engaged in an investigation of the proportions of acids, alkalies, and salts, especially phosphates, in the urine about this time. Coley, op. cit., note 6 above, pp. 37-39.

${ }^{70}$ Rees, op. cit., note 62 above, p. 42.

${ }^{71}$ Idem, op. cit., note 66 above, p. 137.
} 
contribute as much to preventive medicine as to the treatment and cure of established disease, but, cautious as ever, Rees saw the new promise of chemistry in relation to other observations, including the use of the microscope, in an integrated approach to medical diagnosis, for, “. . . if this be neglected, as much evil as benefit may arise from the application of these important means of investigation."72

Amongst the causes of albuminous urine apart from Bright's disease, the most serious and the most difficult to identify were those connected with urinary stone. Rees thought that in these cases the origin of albumin in the urine was due to pus formed as a result of irritation of the mucous membranes of the bladder. Treatment should therefore be designed to remove this irritation and, if successful, "We may then assure ourselves as to the secretion of albumen or not by the kidney and so determine an important fact for the surgeon, who must be influenced not only in respect of operating, but more especially in his prognosis, by this important element in the consideration." ${ }^{33}$ So the medical chemist was to have a hand in decisions about the most drastic forms of treatment, including surgery.

Whilst considering the consequence of irritation of the mucous membranes, Rees put forward some simpler ideas about the formation and structure of urinary calculi. $\mathrm{He}$ ascribed the deposition of earthy phosphates in the urine to the degree of alkalinity caused by inflammation of the mucous surfaces. If only enough alkali is formed to displace ammonia but not to neutralize all the acids of the ammoniacal salts in the urine, the triple phosphate will be deposited, but if there is more alkali present, phosphate of lime will be deposited as well. Rees remarked that the effects of the alkaline secretions of the mucous membranes had been much neglected by Prout, but, since he himself had directed attention to them, others had begun to recognize their importance. ${ }^{74}$ In 1856 , he brought together his observations on the causes and treatment of urinary calculus and further developed his ideas about the importance of the secretion of mucus to provide a simple chemical and mechanical explanation of the progress of this disease, since he had long felt that most of the chemical theories on this subject were too complex.

He began by challenging the idea suggested by Golding Bird, his colleague at Guy's, that oxaluria can be identified as a separate diathesis. ${ }^{75}$ Instead, Rees suggested chemical equations of the type used by Liebig, to show the relationship between uric and oxalic acids. He also described some cases in which oxalates had been found in the urine, but he pointed out that in half of these the oxalate had only appeared after heating, whilst "... the rest are so like what we observe in the ordinary run of dyspeptic cases ... that their relation to the urates and the uric acid

\footnotetext{
${ }^{72}$ Ibid., p. 29.

${ }^{73}$ Idem, op. cit., note 62 above, p. 25

${ }^{74}$ Idem, op. cit., note 66 above, p. 30.

${ }^{75}$ Idem, op. cit., note 59 above, pp. 2-17; for Bird on oxaluria see, Golding Bird, 'Researches into the nature of certain frequent forms of disease characterized by the presence of oxalate of lime in the urine', Lond. med Gaz., 1842, NS. 2: 637-643, 749-754, 793-799; Urinary deposits, their diagnosis, pathology and therapeutical indications, London, 1844 (3rd ed., 1851), pp. 121f. Bird, who referred his readers to Rees, op. cit., note 12 above, "... for minute chemical details connected with the contents of this volume ...", developed his ideas from W. Prout, An inquiry into the nature and treatment of gravel, calculus and other diseases connected with a deranged operation of the urinary organs, London, 1851 (5th ed., 1848), pp. 62-72. Prout thought the oxalic acid diathesis was closely related to diabetes.
} 


\section{N. G. Coley}

diathesis need scarcely be doubted." ${ }^{76}$ Rees also remarked that Lehmann had similarly challenged Bird's notion of oxaluria, ${ }^{77}$ basing his remarks on a critique of Scherer's work. Scherer had spoken of an acid urinary fermentation involving the mucus of the bladder and the urinary pigment resulting in the formation of uric acid and sometimes calcium oxalate. These changes, however, were thought only to occur after the urine had been passed. Rees thought that the excess of uric acid and urates in the urine could occur in the body and that this was the only faulty state of the urine. The insolubility of these compounds led to the first stages of urinary deposits, a fact confirmed by the observation that the great majority of urinary stones were formed on a nucleus of uric acid or its ammonium salt. Oxalates were then formed by the subsequent oxidation of uric acid or urates and the oxalic acid diathesis was, in his view, "... an accidental and unimportant modification of that most significant variation from health which consists in the excretion of uric acid, or its compounds, in abnormally increased proportions."78

Rees was then able to describe a simple process by which a large urinary stone might be formed, for once a small stone had appeared it would irritate the mucous membranes of the bladder. This would release the characteristic alkaline secretion which, in turn, would lead to the deposition of the phosphates. Consequently, according to Rees, the formation of urinary calculi resulted from the initial chemical imbalance of the urine followed by mechanical irritation and the stone might grow to considerable size as a result of long-continued irritation of the mucous membranes of the bladder. The examination of urinary stones seemed to bear this out. Moreover, chemical analysis of the urine would enable physicians to recognize the onset of the disease and so advise the most appropriate treatment.

\section{CONCLUSION}

In attempting an assessment of Rees's contributions to medical chemistry it must be admitted that he made no significant discoveries by which his name is remembered. Nevertheless, there can be little doubt that his work in urine chemistry was both original and important. At Guy's he followed the tradition for medical chemistry that had grown up during the previous half-century. In his work with Richard Bright, for example, Rees took his cue from John Bostock, ${ }^{79}$ who had provided chemical commentaries for Bright's Reports of medical cases, but leading physicians and surgeons at Guy's often encouraged an interest in the collateral sciences amongst promising pupils who seemed likely to maintain Guy's reputation for a more scientific approach to medical practice.

Throughout his career, Rees endeavoured to improve the quality of analytical results for the purposes of clinical interpretation, but, always aware of the practical difficulties, he based his efforts upon his own careful observations. He was perhaps

\footnotetext{
${ }^{78}$ Rees, op. cit., note 59 above, p. 17.

${ }^{77}$ Ibid., p. 18. Lehmann, op. cit., note 58 above, vol. 2, pp. 41-48, see p. 45.

${ }^{78}$ Rees, op. cit., note 59 above, p. 9.

${ }^{79} \mathrm{John}$ Bostock was lecturer in chemistry at Guy's from 1822, and Bright's first collaborator. He was a prolific writer on physiological chemistry, see S. C. Smith, 'The contributions to science of John Bostock, M.D., F.R.S., 1773-1846', unpublished MSc thesis, London University, 1954.
} 
more concerned with reliability than with quantitative accuracy, although he tried to improve that as well. He regarded simplicity as extremely important, as, for instance, in his proposal to use lemon juice in the treatment of rheumatic diseases. ${ }^{80} \mathrm{His}$ contributions in the field of clinical practice were recognized by the fact that between 1856 and 1873 he lectured on the practice of medicine in the medical school at Guy's. Nowhere was it more essential to provide reliable analyses and carefully-worded, circumspect deductions than in the evidence presented in court proceedings concerned with indictments for murder-evidence that would be minutely examined by astute counsel and discredited at the slightest hint of hesitation or doubt. Rees had himself always adopted the most critical stance towards his own and others' chemical observations, always demanding satisfactory evidence before committing himself. ${ }^{\mathbf{}}$ It was due to this quest for objectivity that $\mathrm{A}$. S. Taylor sought his assistance and used the analytical results which Rees supplied in his evidence as an expert witness in many murder trials. In the early 1850 s, too, Rees and Taylor collaborated in editing Pereira's work on materia medica ${ }^{\mathbf{2}}$

Rees's professional career may be considered fairly typical of a successful London physician in the nineteenth century, although he was active for much longer than many of his contemporaries. He served at Guy's until his retirement in 1873, after which he continued as a consultant for some time. From 1843, he was also physician to Pentonville prison, and he had his own private practice in fashionable parts of London from $1837 .^{83} \mathrm{He}$ was elected to the Fellowship of the Royal College of Physicians in 1844 and was later associated with its work, becoming censor in 1852-53 and senior censor in 1863-64. Although shy and retiring, he had a jovial manner and was much in demand as an after-dinner speaker. More importantly, between 1845 and 1869 , he was elected to deliver most of the prestigious medical lectures in London and, since these were always fully reported in the medical press, his name and ideas became widely known throughout the profession. Unfortunately, however, his methods of clinical chemistry appear to have been received with polite interest rather than enthusiasm, and were not much used outside his close circle of friends and colleagues at Guy's. Among chemists, however, his analytical work was well respected and he was a founder member of the Chemical Society in $1841 .^{\mathbf{8 4}}$

\footnotetext{
${ }^{80} \mathrm{G}$. O. Rees, The treatment of rheumatic diseases by lemon juice with illustrative cases from hospital practice, London, Longmans, 1849.

${ }^{81}$ Idem, Hunterian Oration, Hunterian Society, London, 1854.

$82 \mathrm{~J}$. Pereira, The elements of materia medica, 2 parts, London, 1839 (2nd ed., 1842; 3rd ed., 2 vols., 1849-53, part 2 of vol. 2 edited by A. S. Taylor and G. O. Rees; 4 th ed., enlarged and improved by A. S. Taylor and G. O. Rees, 2 vols., London, 1854-57).

${ }^{83}$ At Guy's he became assistant physician in 1843 and full physician thirteen years later; from 1856 until his retirement, he lectured on the practice of medicine in the medical school there. His private practice was first in the family home at 59 Guildford Street, Russell Square, then in Cork Street, and finally at 26 Albemarle Street. According to his friend and colleague Samuel Wilks, "His clients were amongst the better classes and usually sufferers from kidney disease or gout, for the treatment of which disorder he had gained considerable repute." S. Wilks, Proc. $R$. Soc. Lond., 1889, 46: xiii.

${ }^{84}$ The Jubilee of the Chemical Society of London. Record of the proceedings, together with an account of the history and development of the Society, 1841-1891, London, Chemical Society, 1896, p. 118. R. J. Spring, 'The development of chemistry in London in the nineteenth century', unpublished PhD thesis, London University, 1979, p. 74.
} 


\section{N. G. Coley}

In 1882, Rees was made physician-extraordinary to the queen, and it is said that he was also considered for the presidency of the Royal College of Physicians about this time. However, his retiring habits coupled with failing health led to him being passed over. In 1886, he suffered a paralytic stroke and never afterwards regained his former vigour. He died on 27 May 1889, following a second seizure, and is buried in the Abney Park Cemetery in London. 